\title{
A Unique Civil Engineering Capstone Design Course
}

\author{
https://doi.org/10.3991/ijep.v8i1.7667 \\ G. Padmanabhan ${ }^{\square}$, Dinesh Katti, Eakalak Khan, Francis Peloubet \\ North Dakota State University, Fargo, ND, USA \\ g.padmanabhan@ndus.edu \\ Navaratnam Leelaruban \\ Moore Engineering Inc., West Fargo, ND, USA
}

\begin{abstract}
The North Dakota State University, USA, capstone course was developed as a unique model in response to the effort of the Accreditation Board of Engineering and Technology, USA, to streamline and improve design instruction in the curriculum and has steadily evolved to keep pace with the ever-changing technology and the expectations of the profession and the society we serve. A capstone design course by definition should be a design experience for students in the final year before graduation integrating all major design concepts they have learned up until then in the program. Carefully chosen real world projects with design content in all sub-disciplines of civil engineering are assigned in this team-taught course. Faculty and practicing professionals make presentations on design process; project management; leadership in an engineering environment; and public policy; global perspectives in engineering; and professional career and licensure. Practicing professionals also critique the final student presentations. Students work in teams with number of faculty serving as technical consultants, and a faculty mentor for each team to provide nontechnical guidance and direction. The course requires students to demonstrate mastery of the curriculum and to work with others in a team environment. Course assessment includes evaluation of the final design, presentations, written technical reports, project design schedule, a project design journal, and reaction papers.
\end{abstract}

Keywords-civil engineering curriculum, capstone design course, program accreditation, course objectives, outcome assessment

\section{Introduction}

The Accreditation Board for Engineering and Technology (ABET) in the USA has been raising concerns for a long time about the fragmented approach taken by various civil engineering programs to increase the total design content in their curricula. ABET 2003-2004 criteria requires that all engineering students participate in a major design experience based on prior course work, engineering standards, and realistic constraints. The ABET emphasized the need for at least one course which is primarily design-oriented, preferably at the senior level, and integrated on the accumulated 
background of the curricular components be included in the curriculum [1-3]. The concept is similar to the one described by Wagenaar in the field of sociology [4]. Wagenaar argued capstone should be an "advanced introductory" course that requires students to revisit introductory course concepts while integrating the in-depth understanding gained through courses focused on substantive knowledge, methods, and theory. The ABET challenged colleges of engineering in the USA to produce graduates with professional as well as technical skills. Specifically, ABET Criterion 3 (Program Outcomes and Assessment) outlines the desired attributes for graduate engineers [2]. Capstone design courses are one of the most effective ways for engineering departments to facilitate the outcomes described by ABET Criterion 3. Capstone design courses not only need to provide a meaningful design experience, but also need to create opportunities to begin the process of becoming engineering professionals [5]. Capstone course should be designed as an integrative experience that rounds out student's participation in the curriculum and a transitional experience that prepares students to move past academia [6].

A seminal survey of engineering capstone courses throughout the United States for the purpose of gaining an understanding of the structure of capstone courses taught prior to 1994 was reported by Todd et al. [7]. Another survey was reported in 2005 by Howe and Wilbarger [8]. According to this survey, one-to -two semester course structure with simultaneous class and project components remained popular while course content showed a greater breadth and a learning towards professional skills. External project sourcing through industry had increased and was the most common approach. Institutions involved only very few faculty in the formal instruction of the course. A tremendous increase in the variety of projects was notable. The survey also pointed out a high rating of the educational value of the course by faculty and students. Most of the courses had some form of assessment component built into them [8]. The most recent survey reported was in 2016 following up on the earlier surveys of 1994 and 2005 augmented with new questions. The survey reported that a variety of logistical and pedagogical practices are being used. Authors conclude that this may be the time to begin determining "effective" practices. Response tables provided in this paper gives us a peek into common practices in the structure, logistics, pedagogy, and implementation of capstone courses [9]. The results of another survey reported in 2007 revealed that most desirable features were the design experience based on realistic conditions, students schedule the design activities, and the products of the design include drawn plans, a written report, and an oral presentation. Faculty and students saw the value of having 3-5 students in a team. Faculty also thought students logging activities was strongly desirable. Faculty and engineers in the public sector thought evaluation of performance of individual members of design teams is important [10].

\section{Capstone Design Course at North Dakota State University (NDSU) Civil Engineering Program}

In response to the call by ABET to integrate the narrow - focus design offered in individual courses to the overall total civil engineering design experience, a capstone 
course was instituted at NDSU Civil Engineering program and this course has successfully evolved over the years to the present status [11-14].

In the years 1990-92, the capstone course was offered as a 2-quarter, 3-credit course in the senior year. In the first quarter, students worked on preparing a proposal and presenting it. In the second quarter, students carried out the design and presented their final product. The details and experience with this course two years after it was established can be found in Andersen, et al. [11]. Although the course fulfilled the ABET criterion of a "combined background of curricular components, one recommendation for improvement was to bring in input by additional professionals from the engineering community at the beginning of the course that would give more of a realworld atmosphere to the project. These individuals could also be used to critique the designs at the final presentations. Example projects assigned in this period included design of an interstate highway rest area/information center and the design of a small regional airport. Actual field sites were selected for these projects.

In the years 1992-96, the capstone design course was offered as a 1-semester 2credit course. At this time, the following goals had been established for future offering of the course based on discussions by the faculty [12]: provide an open-ended design experience encompassing the major subject areas of civil engineering; allow students address various socio-economic, environmental, and political issues of an engineering project; provide students an opportunity to work in a team in organizing and carrying out the design of an engineering project; and provide students an opportunity to develop oral and written communication skills.

In this period, artificial elements were added to the projects selected for the course to include all aspects of civil engineering. Contour maps, soils data, traffic counts, water table data were made available for the selected sites. Some of the projects were borrowed from the undergraduate theses completed by the NDSU Architecture department, thus providing an opportunity for the students to interact with and interpret the architect's design. The process of group assignment was improved to ensure equitable distribution of responsibilities among the members. Students were asked to submit an organizational chart indicating who is responsible for what in the group. Each member in the group was expected to participate in the preliminary and final presentations. Each student was also required to prepare at least one of the final drawings. With only one semester available the groups had to immediately begin collecting data and examining the alternatives for their design. Usage of Computer Aided Design (CAD) drawings, Microsoft Word-processors and PowerPoint software were required for preparing reports and presentations [12].

In the years 1996-2002, two more goals were added to the already developed goals of the course: provide students with an opportunity to interact with the community and seek their feedback; and provide an opportunity to develop life-long learning habits and skills to relate seemingly unrelated ideas and integrate them in the overall design.

The Civil Engineering Department started using community-based projects in the capstone course to emphasize the importance of community integration in the civil engineering profession. Real-life projects for the course are carefully selected from the community. Faculty members expended considerable time in seeking suitable 
community-based projects for the course. Examples included: a water treatment plant component; a river marina; an interstate highway ramp; and slope stability problems. These projects had close cooperation from the community and the consulting engineers. Their input was used for defining the project and providing the students with the necessary information. Also, students were asked to present results to the faculty, community, and consultants. The feedback from clients during and after the questionanswer sessions provided a valuable learning opportunity for students [13].

Since 2002, several changes have been made in the content, structure, operation, and assessment of the course. The importance of community-relevance of the projects has been recognized and is increasingly brought to bear on the course in recent years. The course has successfully kept pace with the ABET requirements for changes in assessment procedures over the years to move from teaching-centered to learningcentered and outcome-based strategy. Requirements have moved from requiring and grading only the final reports in the past to requiring and grading preliminary reports, presentations, reaction papers, etc., and providing feedback to the student. Use of instructional technology beginning from the use of Power Point presentations to AutoCAD to Blackboard teaching platform have been adopted promptly as the course evolved.

Currently, the course has evolved into a unique civil engineering capstone design course, and is described in the remaining sections of this paper.

\subsection{A Unique Model}

Currently, the capstone design course is offered with 3 credits in both Fall and Spring semesters. Figure 1 shows the capstone course model of Civil Engineering program of North Dakota State University. Only the senior students in their last semester are allowed to register for the course. It is a team-taught course. Carefully chosen real world projects with design content in all sub-disciplines of civil engineering are assigned. In addition to project presentations by industry and/or community, the course also has presentations by the faculty on their respective subarea parts of the project. Also included are guest presentations on topics such as professionalism, ethics, societal impacts of civil engineering projects, and professional registration. In addition, topics such as design process, leadership, public policy and global perspective on civil engineering, etc. are presented by experts. Students are asked to submit reaction papers on these special topics. All relevant course materials and presentations are made available to the students via the teaching platform, BlackBoard, which is also used for communicating with students beyond class hours. Typical samples of the project and course information, and format for reaction papers are shown in the Appendix A-B.

The broad goals of the course are to provide opportunity for students to experience real world project design [15], to apply and integrate the technical knowledge they have gained from various courses in the civil engineering curriculum $[5,6]$, to learn skills needed for a professional career in civil engineering $[5,6]$; to work in a team environment [16]; and to develop communication, and presentation skills both oral and written $[17,18]$. In keeping with these goals, the following broad course objec- 
tives expect the students to acquire the ability to (i) successfully complete the discovery phase of the assigned civil engineering design project, (ii) utilize the acquired project data, plans, references, tools, techniques, and other resources appropriately, accurately and effectively, (iii) apply knowledge obtained from undergraduate curriculum courses, (iv) work in design teams to complete a complex multidisciplinary design project, (v) prepare and present project design results as formal technical reports (written) and oral presentations using visual and graphical communication tools, (vi) understand the importance of professionalism, ethical responsibilities in a societal context, and continual/life-long learning to handle future engineering project designs, and (vii) understand how and why 'real-world' engineering projects impact or are impacted by contemporary issues and public policies in a global and societal context.

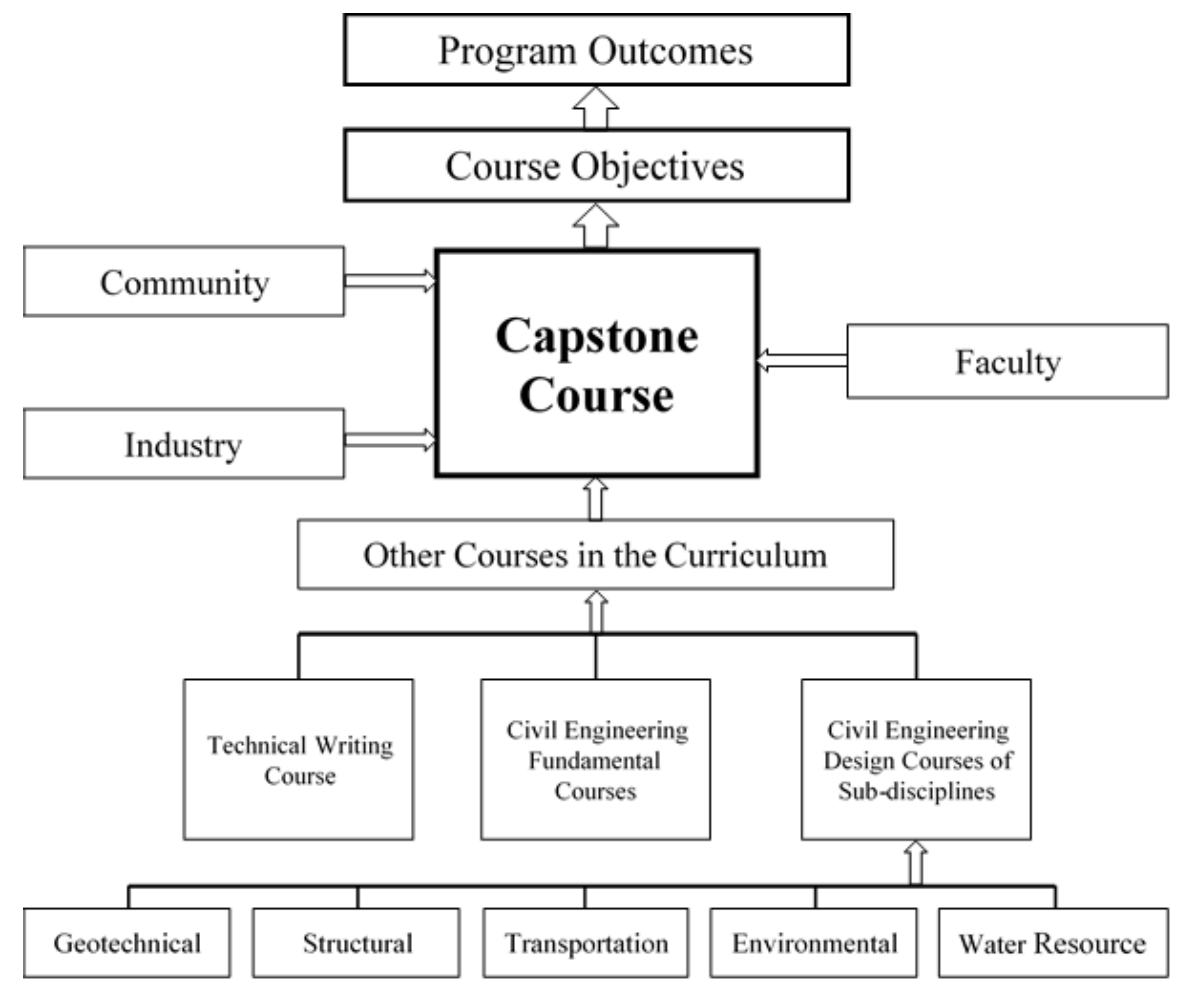

Fig. 1. The Capstone Course Model of Civil Engineering Program of North Dakota State University, USA

Some of the unique elements of the course are:

1. Real life community projects with meaningful design content reflecting real-world engineering design practices are assigned.

2. Students, working in groups of five in a team, complete the design project, develop the documentation of the engineering project design (i.e. project analysis, design calculations, drawings, material quantities, basic cost estimate, design schedule, 
and an overall work plan), and present results in verbal, written, and electronic formats.

3. The course fulfills the expectations in relation to ABET requirements.

4. Industry collaboration

5. Selected projects are pruned for scope and size.

6. Projects are tweaked to include all subareas of civil engineering (Environmental, Geotechnical, Structural, Transportation, and Water Resources engineering)

7. Course has a designated coordinating faculty.

8. Faculty from all subareas of civil engineering participate in the instruction and mentoring.

9. Guest speakers from the profession and project owners present in the course.

10. Course is assessed for ABET outcomes using several assessment tools [19]

11. Peer evaluation of individual students by other students in the team

12. Student feedback and comments are used to improve the course.

\subsection{Course Structure and Dynamics}

One faculty member is assigned as a facilitator and coordinator for the course by the Chair of the department. The course facilitator's responsibilities include convening meetings to select, review, and scope the design project; maintaining the course on Blackboard web site, course documentation; project documentation; forming student design teams; ensuring student awareness of course requirements and schedule; scheduling several class lectures; scheduling ABET topic guest speakers; coordinating faculty scoring of assessment tools; scoring ABET topic reaction papers; scheduling student design team presentations; recording and posting all student assessment scores; and calculation and posting of final course grades.

Potential projects in the community are discussed by the faculty at least a semester ahead and one selected for the course in the subsequent semester. After discussing with the project sponsor it is reviewed by the Department Chairperson, faculty, and the assigned capstone facilitator/coordinator. Once the design project is approved, all relevant and necessary project documents are identified and assembled.

Five faculty members are assigned to the capstone project to represent each of the five subareas: environmental, geotechnical, structural, transportation, and water resources. They serve as both technical consultants that mimic principal engineers of the firm and as clients that mimic the project owners who hired the firm. These five faculty members scope the project to ensure a manageable level and volume of design work for the students. Each faculty member presents design project information and requirements for their specific subareas to the capstone class. They also prepare technical report writing requirements for their respective areas and post the information on the course Blackboard web site.

Five-member student design teams are formed. Each team member selects his/her preferred first and second subarea of interest. Each team selects a team member to serve as team leader and an assistant team leader. Teams select a primary member and a secondary member for each subarea. This process mimics the task assignment for a project within an engineering design firm to a team of engineers within the firm. After 
the project scope has been defined, each team is tasked with preparing a design work plan, determining design parameters, evaluating design alternatives, design preparation, and materials cost estimating. Initial team activities are devoted to what is referred to as the 'discovery phase' of the project. Teams make team member assignments, develop a work plan, and locate all design references, manuals, standards, aids, and other design literature that may be required but was not initially provided by the faculty members.

Other faculty not serving as technical consultants to the design teams, are assigned as mentors to the teams, one faculty per team. Faculty mentors provide non-technical information, direction and motivation to each student design team. They help the teams stay focused and on task. They offer suggestions on time management, team dynamics issues, communications, locating information, and other relevant needs each team may encounter. Teams are encouraged to meet at least weekly with their faculty mentors to review their weekly design activity project journal entries. This activity mimics the project design progress meetings between the design team and the principal engineers at an engineering design firm.

All elements of the course structure and dynamics were adopted after careful discussions during regular department faculty meetings. These discussions have greatly contributed for the improvement of the course in terms of both the students and faculty perspectives. An example is a modification that satisfied student concerns about course work load and ABET professional preparation requirements. Beginning with the 2012-2013 academic year, the number of credit hours was increased from two to three providing students more time to work on the design project and more class time for topic presentations and activities to address an ABET program criterion on an ability to explain basic concepts in management, business, public policy, and leadership.

\subsection{Course Expectations and Assessment}

Several assessment tools such as preliminary mid-semester report, final end-of-thesemester written report, preliminary and final presentations, reaction papers, group peer evaluation, and student journals are used for student assessment. Table 1 shows the grading scheme for the course. Major objective of the course is to enhance the ability of graduating students to apply knowledge and skills from courses in the civil engineering (CE) curriculum by making sure the capstone course project mimics the 'real world' civil engineering projects.

Rubrics based scoring forms are made available to students and are used by faculty to score assessment tools. Appendix $\mathrm{C}$ shows a sample of rubrics used for scoring final design report. Methods used for grading the teams and individual students in the team are described in Appendix D-F. Students have the option to use peer assessed grading to address negative group dynamic issues. A weekly student journal template is shown in Appendix G. Students are expected to adhere to the report writing requirements for preparing their conceptual, preliminary design, and final design reports (Appendix H). 
Table 1. Grading scheme for the NDSU capstone course

\begin{tabular}{lc}
\hline \multicolumn{1}{c}{ Items } & Weight (\%) \\
\hline Reaction Papers (RP) (5 @ 3pts each) & 15 \\
Conceptual Design Report - \#1 \& Project Work Plan (PWP) & 10 \\
Mid-Semester Oral Presentation & 10 \\
Mid-Semester Preliminary Design Report - \#2 \& PWP & 20 \\
Final Project Oral Presentation & 10 \\
Final Project Design Report - \#3 & 30 \\
Project Design Journal & 5 \\
Total & $\mathbf{1 0 0}$ \\
\hline Grade Distribution: $90-100 \%-\mathbf{A} ; 80-89.9 \%-\mathbf{B} ; 70-79.9 \%-\mathbf{C} ; 60-69.9 \% \cdot \mathbf{D} ;$ Below $60 \%: \mathbf{F} \cdot$
\end{tabular}

Grade Distribution: 90-100\%-A; 80 - 89.9\%-B; 70 - 79.9\%-C; 60 - 69.9\%: D; Below 60\%: F.

[NOTE: Student Teams may select Group Grading or Peer Assessment Grading.]

The following student activities in the course are assessed:

1. Group organization, communication, and coordination: This activity requires students to experience and apply group dynamics concepts in an engineering design project environment. Students use a variety of face to face, mobile, computer, and electronic methods to organize their design teams, as well as communicate and coordinate their project activities. Students gain experience assigning and taking responsibility for project duties and functions.

2. Prepare a design project work plan: The activity requires students to develop an approach and timeline for identifying and completing project components and work tasks. Computer software, such as Microsoft ${ }^{\mathrm{TM}}$ Project ${ }^{\circledR}$, can be used to prepare the project work plan or it can be done manually utilizing the principles of PERT and/or GANT chart development. Students gain experience with the importance of time management on CE projects.

3. Maintain an up-to-date project design journal: Students learn the importance of maintaining focus on project activities through periodic review of the status of project activities and gain experience with the importance of time, personnel, and resource management. Students coordinate their activities with faculty mentors similar to meetings with a CE firm's principal or senior project engineers.

4. Determine design parameters, evaluate alternatives, and perform $\mathrm{CE}$ calculations that are part of technical design reports: Students apply knowledge and skills from their CE curriculum courses to an open ended CE design project and learn to locate and obtain information, documents, design aids, etc. not provided by faculty, but required to complete the design project. Students learn to analyze a CE design challenge to determine a result that satisfies all project constraints.

5. Write technical design reports: Student design teams write a Conceptual Project Design report that also includes the team's work plan, a Preliminary Project Design report and a Final Project Design report.

6. Prepare a basic materials and cost estimate of the final project design: Students determine project materials, quantities, and equipment, and prepare a basic project cost estimate using published sources.

7. Make formal design project presentations: Student design teams present their preliminary project design at mid-semester and make a formal presentation of their 
final project design at the end of the semester to faculty and clients using presentation software, such as Microsoft ${ }^{\mathrm{TM}}$ PowerPoint ${ }^{\circledR}$, to prepare multimedia materials.

8. Attend presentations by practicing professionals: Students attend five ABETemphasized CE profession topic presentations and write a short reaction paper for each presentation. The topics include; Civil Engineering Design Process, Profession and Licensure, Global Perspective, Business, and Leadership.

\subsection{Recent Projects}

Projects recently used in the capstone design course are listed below to give a flavor of the type of projects:

1. A performing arts auditorium and athletic competition size gymnasium for a K-12 school

2. A new medical center

3. Flood protection for a city office building complex

4. A community wastewater treatment system relocation

5. Civil infrastructure for a residential housing development

6. A city park, RV camping facilities, and community center

7. An airport international terminal, runway extension, and taxiways

8. An agricultural equipment museum and research center

9. Condominium garages, driveway, and parking lot reconstruction

10. A race park and speedway with associated buildings

\subsection{Student Feedback}

Student concerns of the course and the corresponding actions taken to address them are summarized and submitted by the instructor to the department Chair at the end of the course each semester. Some weaknesses indicated and the actions taken to improve the course are shown here as examples:

Over a period of several years a consistent concern expressed by the students was the course was too demanding in terms of time and effort for two credits. In response, the department decided to increase the credit to three. The idea of extending the course to two semesters was also considered but was not implemented due to difficulties in having the same students registered for the course in both semesters.

Another concern was lack of student understanding regarding the concept and procedures of the course. In response, we provided more detailed written and verbal explanation of course and project purpose, requirements, and procedures, applied the use of rubrics for determining scoring criteria, simplified the scoring format and calculations, and added pre- and post-testing relative to professional development assignments. However, pre- and post-testing of student reports on the ABET topics presented in the class was logistically impossible to continue. It was tried in one semester for the Professional Engineering and Tau Beta Pi (TBP) Engineering Futures topics. With the addition of more ABET topics and not having advanced knowledge 
of presentation content, it became too difficult to continue this form of outcome assessment.

Another student concern was to allow electronic submission. In response, we put the course on BlackBoard so students could access course material any time they want from anywhere with internet access. Students could also submit their reports, journals, and reaction papers via BlackBoard.

Yet another suggestion by the students was to increase the opportunity for faculty interaction time to make sure they are on the right track with respect to the project progress and time management and also to make sure all students in the groups participate without slack. In response, we assigned faculty mentors for each group in addition to their discipline specific consultants

\subsection{Course Assessment}

The course elements used for assessment are:

- Mid-semester and final written report [for all seven course objectives]

- Mid-semester and final oral presentation [for the last four course objectives]

- Student reaction papers [for the last two course objectives]

- Group Dynamics [for course objective 4]

- Student journals [for course objective 6]

- Student survey on the course elements [for all seven course objectives]

The performances of students in the capstone course have been very consistent in the past several years. The average score has been in a narrow range of 84 to 89 (out of 100) for both the oral presentations and written reports. Based on the typical criteria used for assessing other civil engineering courses in the curriculum, the score range of 84 to 89 corresponds to a scale of 4 ( 1 to 5 scale) or a very good level. The performance target for all objectives for all courses in the curriculum is a rating of 80 or a scale of 4 . Therefore, the performance meets the target. However, revisions are being planned to further enhance learning and assessment. The planned revision includes

- Incorporate a mid-semester evaluation to collect student input relative to the course (and course objectives).

- Provide a short refresher training on the use of AutoCAD since there is a big time gap between when the students normally take the CAD course (first semester of sophomore year) and the capstone course (last semester before graduation).

Though no formal assessment of the course objective of emulating real-world project work could be carried out because of the practical difficulty of having practicing professionals evaluate the final design due to their time limitation and work schedule, occasionally we did have practitioners evaluate the presentations. Each semester engineering practitioners involved in the project are invited to make class presentations. They also are invited to participate in evaluating design team presentations. We could not have practitioners evaluate the design reports because of the short turnaround time 
requirements. Some of the work products (designs) were adopted (with modifications) by project owners. Students had plenty of opportunity to meet with clients (actual sponsors or owners of the project) to talk about the project conceptualization and with practicing professionals about the design processes and alternatives. Most of the comments received during exit interviews related to capstone course are on how open-ended the course is. Students are uncomfortable and struggling with that and prefer a perfectly well defined project. Students somehow have this pre-conception that all project details are clearly defined in the real world. However, at the end of the project students seem to reluctantly accept that real world problems are seldom well defined and almost always are open-ended.

\section{Conclusion}

The capstone design course at NDSU continues to be a work in progress as the department responds to student and ABET requests, concerns, and suggestions. The course, in its present form, encompasses those elements deemed to be important to the development of student's ability to integrate all aspects of civil engineering into projects and the soft skills necessary for successful practice of civil engineering profession.

The model is unique in many respects including industry collaboration, community participation, presentations by experts in the profession, and multiple faculty involvement. After 2000, ABET encouraged learning-centered rather than teachingcentered assessment of courses. Under this concept it is essential to define expected outcomes of the courses and to assess them. New learning-centered assessment methodologies and tools have been developed since 2000 and have matured into standard practice. The performance of students towards the ABET-expected program outcomes will continue to be monitored. Based on the positive buy-in by the faculty and students, the current capstone course model will be continued at NDSU in the future. It is a unique model that could be successfully emulated in other civil engineering programs.

\section{Acknowledgment}

Authors would like to acknowledge all members of NDSU Civil and Environmental Engineering department faculty, and presenters from the industry and community for contributing to the capstone course.

\section{$5 \quad$ References}

[1] ABET (2002). ABET 2003-2004 Criteria for Accrediting Engineering Programs, Accreditation Board for Engineering and Technology, Baltimore, MD, USA.

[2] ASCE (2002). Commentary to Civil Engineering Program Criteria, American Society of Civil Engineers, Version of May 2002. 
[3] Davis, W. J., Mays, T. W., and Plemmons, J. K. (2004). Rethinking Capstone Courses in Civil Engineering: A Response to ABET 2003-2004 Criteria for Accrediting Engineering Programs. In Proceedings of the American Society of Engineering Educators Southeaster Section Conference, April 4-6, 2004, Auburn, Alabama, USA. available at: http://se.asee.org/proceedings/ASEE2004/ASEE2004SE.htm [Accessed: August 21, 2017]

[4] Wagenaar, T. C. (1993). The capstone course, Teaching Sociology, 21(3): 209-214. https://doi.org/10.2307/1319011

[5] Tooley, M. S. and Hall, K. D. (1999). Using A Capstone Design Course to Ensure ABET 2000 Program Outcomes. In ASEE Annual Conference and Exposition, June 20-23, 1999, Charlotte, NC, USA. available at: https://peer.asee.org/8024 [Accessed: August 21, 2017]

[6] Heinemann, R. L. (1997). The Senior Capstone, Dome or Spire? In $83^{\text {rd }}$ Annual Meeting of the National Communication Association, November 19-23, 1997, Chicago, IL, USA. available at: http://files.eric.ed.gov/fulltext/ED415557.pdf [Accessed: August 21, 2017]

[7] Todd, R., Magleby, S., Sorenson, C., Swan, B., and Anthony, D. (1995). A survey of capstone engineering courses in North America, Journal of Engineering Education, 84: 165-174. https://doi.org/10.1002/j.2168-9830.1995.tb00163.x

[8] Howe, S. and Wilbarger, J. (2006). National survey of engineering capstone design courses. In Proceeding of the American Society for Engineering Education Annual Conference and Exposition, June 18-21, 2006, Chicago, IL, USA. available at: https://peer.asee.org/1023 [Accessed: August 29, 2017]

[9] Howe, S., Poulos, S. L., and Rosenbauer, L. M. (2016). The 2015 capstone design survey: Observations from the front lines. In Proceeding of the American Society for Engineering Education Annual Conference and Exposition, June 26-29, 2016, New Orleans, LA, USA. available at: https://peer.asee.org/26085 [Accessed: August 29, 2017]

[10] Seals, R. K., Wilmot, C. G., Williams, M. B. (2007). Mandatory and Desirable Elements of a Capstone Design Course. National Capstone Design Course Conference, June 13-15, 2007, Boulder, CO, USA. available at: http://www.capstoneconf.org/resources/2007 Proceedings/Capstone Conference Program 2007.pdf [Accessed: August 29, 2017]

[11] Andersen, D. A. (1992). Civil engineering capstone design course, Journal of of Professional Issues in Engineering and Education and Practice, 118(3): 279-283. https://doi.org/10.1061/(ASCE)1052-3928(1992)118:3(279)

[12] Padmanabhan, G., Bengtson, M. L. and Andersen, D. A. (1996). Evolution of a civil engineering capstone design course. In Proceeding of the 58th Annual American Society for Engineering Education North Midwest Section Meeting, Oct. 3-5, 1996, Fargo, ND, USA.

[13] Padmanabhan, G. and Katti, D. (2002). Using community-based projects in civil engineering capstone courses, Journal of Professional Issues in Engineering Education and Practice, 128(1): 12-18, https://doi.org/10.1061/(ASCE)1052-3928(2002)128:1(12)

[14] Peloubet, F., Khan, E. and Padmanabhan, G. (2013. The Anatomy of North Dakota State University Civil Engineering Capstone Design Course. In Proceeding of the American Society for Engineering Education North Midwest Section Conference, October 17-18, 2013, Fargo, North Dakota, USA. available at: http://www.whavenlabs.com/ASEECon ference/html/papers/ASEE-NMWSC2013-0022.pdf [Accessed: August 29, 2017]

[15] Hanna, A. S. and Sullivan, K. T. (2005). Bridging the gap between academics and practice: A capstone design experience, Journal of Professional Issues in Engineering Education and Practice, 131(1): 59-62, https://doi.org/10.1061/(ASCE)1052-3928(2005)131:1(59)

[16] Emanuel, J. T. and Worthington, K. (1989). Team oriented capstone design course management: A new approach to team formulation and evaluation. In Proceeding of the 
Frontiers in Education Conference, October 15-17, 1989, Binghamton, NY, USA. https://doi.org/10.1109/FIE.1989.69408

[17] Paretti, M. C. (2008). Teaching communication in capstone design: The role of the instructor in situated learning, Journal of Engineering Education, 97(4): 491-503, https://doi.org/10.1002/j.2168-9830.2008.tb00995.x

[18] Blicblau, A.S. and Dini, K. (2012). Intervention in Engineering Students' Final Year Capstone Research Projects to Enhance Their Written, Oral and Presentation Skills, International Journal of Engineering Pedagogy, 2(3):11-18, https://doi.org/10.3991/ ijep.v2i3.2107

[19] Biney, P. (2007). Assessing ABET Outcomes Using Capstone Design Courses. In Proceeding of the American Society for Engineering Education Annual Conference and Exposition. June 24-27, 2007, Honolulu, Hawaii,USA. available at: https://peer.asee.org/ 2348 [Accessed: August 30, 2017]

\section{Authors}

G. Padmanabhan is a Professor Emeritus of the Civil and Environmental Engineering department of North Dakota State University, Fargo, North Dakota, USA. He is a Fellow of the American Society of Civil Engineers (ASCE) and a long-standing member of the American Society of Engineering Education (ASEE). He served as the department Chair for four years. He has directed North Dakota Water Resources Research Institute, USA for about 15 years. He has published in IJEP, ASCE, and ASEE among other journals. He has made numerous presentations in ASEE conferences on engineering education and outreach.

Dinesh Katti is Professor and former Chair of the Civil and Environmental Engineering Department of North Dakota State University, Fargo, North Dakota, USA. He has served as department Chair for about 10 years and as Associate Dean of Research for about 4 years. He has published extensively in ASCE journals. He has made numerous presentations in ASCE conferences. He is an Associate Editor of the Journal of Engineering Mechanics and also Journal of Nanomechanics and Micromechanics. He has served as Editor for a special in the ASCE Journal of Engineering Mechanics. Dr. Katti is a member of the ASCE Body of Knowledge committee engaged in developing future curricula for engineering programs in the US. He is fellow of the Engineering Mechanics Institute.

Eakalak Khan is a Professor in the Civil and Environmental Engineering department of North Dakota State University, Fargo, North Dakota, USA. He served as the Chair of the department from 2010 to 2013. Currently, he is the Director of North Dakota Water Resources Research Institute. He has published extensively in water and wastewater treatment, and bioremediation. He has made numerous presentations in national and international conferences. He is an Associate Editor of Water Environment and Research and ASCE Journal of Hazardous, Toxic and Radioactive Waste. He is a member of the Academic Committee of Water Environment Federation.

Francis Peloubet is an adjunct faculty of the Civil and Environmental Engineering department of North Dakota State University, Fargo, North Dakota, USA. He has 
been coordinating the NDSU civil engineering capstone course for several years. He has also taught two general engineering courses, History of Technology and Impact of Technology on Society at NDSU. He was closely involved with coordinating the dayto-day instruction of the course from developing project scope and description all the way to course assessment processes.

Navaratnam Leelaruban is a civil engineer with the consulting firm Moore Engineering Inc., West Fargo, North Dakota, USA. He recently graduated with a Ph. D from the Civil and Environmental Engineering department of NDSU. He had assisted faculty in teaching several undergraduate courses during his graduate studies.

Article submitted 04 September 2017. Resubmitted02 November 2017. Final acceptance 04 February 2018. Final version published as submitted by the authors. 


\section{Appendices}

\section{Appendix A:}

\section{GENERAL PROJECT INFORMATION}

The new 384 bed, 11 story, 1 million square foot Fargo Sanford Medical Center and Central Energy Plant proposed for the city of Fargo, ND will be located on the south side of I-94 at the intersection between Veteran's Boulevard and 51st Street in Fargo, ND (Fig A1). Some of the hospital services that will initially be housed in the new building are Children's/Pediatric Intensive Care Unit (PICU), Trauma/Operating Rooms, Orthopedics/Neurosurgery, Heart Surgery/Interventional Cardiology and Emergency Services.

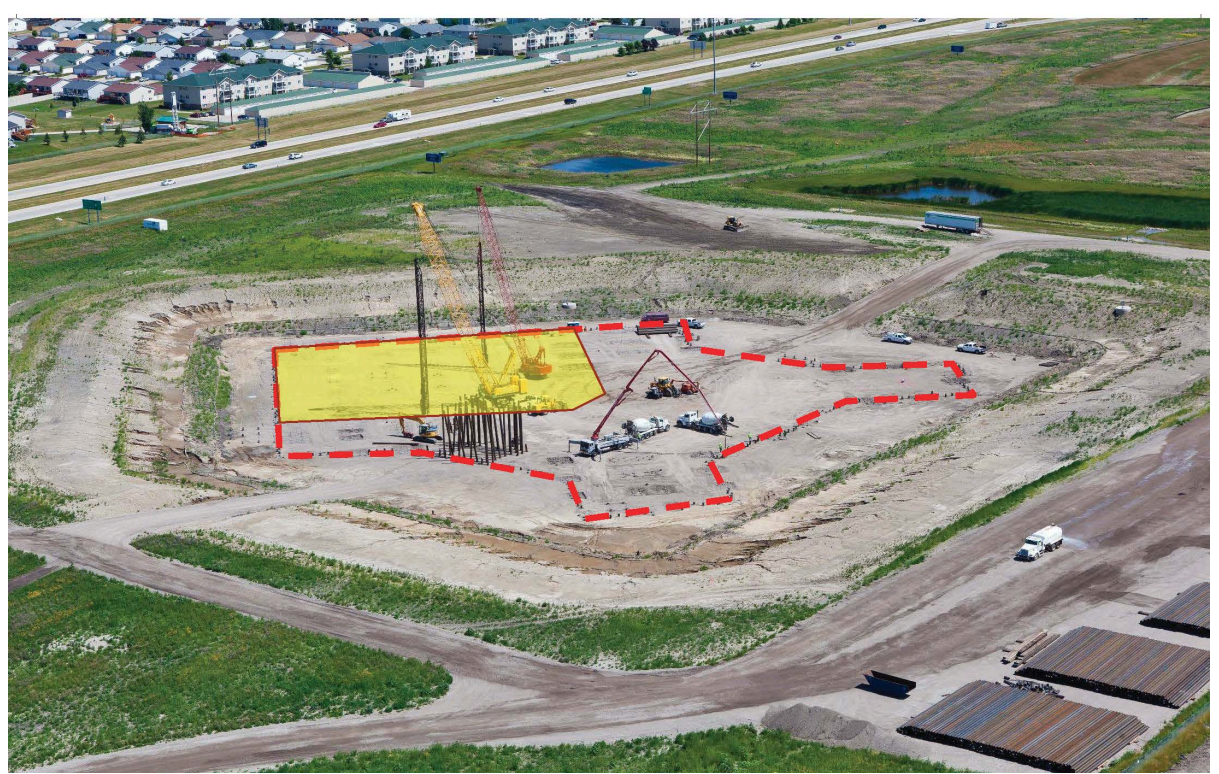

Fig. A1. The proposed new Sanford Medical Center, Fargo, ND.

\section{Project Facts:}

- Sanford's new medical center will be located on the south side of I-94 at the intersection of Veteran's Boulevard and 51st Street, Fargo, ND.

- $\$ 494$ million, 1 million square feet, 11 stories, 384 beds, 28 operating rooms, 51 ER bays, to be completed in 2016-2017

- 109 acres, allowing for future expansion

- Local companies involved with the project include Hebron Brick Company, S \& S Landscaping, MEI, Dakota Fence, Industrial Builders and many more.

- A helipad is located directly above the emergency center and near the operating rooms, creating optimal access.

- Medical services to be housed in the new building remain the same and include a majority of Sanford's inpatient hospital units: Children's/Pediatric Intensive Care 
Unit (PICU), Trauma/Operating Rooms, Orthopedics/Neurosurgery, Heart Surgery/Interventional Cardiology and Emergency Services.

- The project is designed to meet LEED qualifications in energy and environmental areas.

\section{CAPSTONE COURSE PROJECT INFORMATION}

The main objective of the Spring 2015 capstone course is to design a part of the proposed new Sanford Hospital for the city of Fargo, ND (highlighted area of Figure A1). The design should address environmental, geotechnical, structural, transportation, and water resources components along with preliminary cost estimation for each component.

FACULTY TECHNICAL CONSULTANTS

DESIGN TASK

AREA

Faculty name and contact information

Faculty name and contact information

Water Resources

Faculty name and contact information

Geotechnical

Faculty name and contact information

Transportation

Faculty name and contact information

Environmental

Structural

\section{CAPSTONE FACILITATOR/COORDINATOR}

Faculty name and contact information

\section{STUDENT DESIGN TEAMS}

Class members will create 12 civil engineering firms (capstone project design teams) 11 teams with 5 and 1 team with 4 student engineers. Each firm will create a company name (logo optional). Firms will select a project leader and an assistant to manage the overall design effort. Firms will select a team member to lead the design effort for each of the five (5) civil engineering disciplines and a team member to assist each CE discipline leader. Teams will work with a Faculty Mentor who will establish a weekly meeting schedule to help guide each design team. This Spring 2015 semester the assignments are as follows;

Faculty name and contact information Faculty name and contact information Faculty name and contact information $\# 11$

Faculty name and contact information Faculty name and contact information Faculty name and contact information Faculty name and contact information Faculty name and contact information \#12

Faculty name and contact information \#10

\author{
Design Team \#1 \\ Design Team \#2 \\ Design Teams \#3 \&
}

Design Team \#4

Design Team \#5

Design Team \#6

Design Team \#7

Design Teams \#8 \&

Design Teams \#9 \& 


\section{GENERAL TEAM REQUIREMENTS}

- Select a Design Team Member as a team leader and an assistant to manage the overall design effort. Identify all design components and list all individual parts of the design for each task.

- Prepare a project design and management work plan and schedule. Select a team member to be responsible for each CE discipline, select a team member to assist each CE discipline leader, and list team member responsibilities.

- Provide an estimate of material quantities and a basic cost estimate for the project. Prepare a topographic site plan of the project as part of the design report.

- Prepare AutoCAD drawings of all design components as required by the Capstone Faculty Consultants. Keep a project journal and prepare weekly journal entries for weekly review with team mentors.

- Prepare weekly design journal work status reports. [Dates determined by Faculty Mentor.] Work Plan \& Conceptual Design Report -Due date:

- Mid-Semester Preliminary Design Report - Due date:

- End of Semester Final Design Report - Due date:

- Prepare MS PowerPoint media and make oral presentations. [Dates subject to change.] Mid-Semester Presentations - Schedule date:

- End of Semester Presentations - Schedule date:

PROJECT DESIGN TASKS [Capstone faculty will post their specific requirements for each sub-discipline on Blackboard.]

ENVIRONMENTAL TASK AREA - water and wastewater treatment, environmental impact assessments (BMPs for site drainage plan, noise, solid waste, air and water pollution, \& hazardous materials.)

GEOTECHNICAL TASK AREA - soil conditions, foundations, retaining walls, and embankments.

STRUCTURAL TASK AREA - building/s and other structures.

TRANSPORTATION TASK AREA - streets, intersections, parking lots, pavements, pedestrian walkways, trails, etc.

WATER RESOURCES TASK AREA - stream flow analysis, flood routing, storm water collection, pumping, detention, \&/or routing, site drainage, water storage, water and wastewater pipelines. 


\section{Appendix B:}

\section{REACTION PAPER FORMAT AND CONTENT}

1. Each student will submit five (5) Reaction Papers based on the topics listed in the course syllabus.

2. Papers will be submitted based on the schedule in the course syllabus that may be adjusted as necessary due to unknown factors, such as speaker schedules and availability.

3. Reaction Papers will be submitted to the course coordinator electronically by email attachment as an MS Word .doc. or Adobe .pdf file by the published due dates.

4. Reaction Papers shall be 2 pages long formatted for 8.5 "x 11 " paper with 1 " margins on all four sides, 1.25 inch line spacing, and 10-12 pt Times New Roman or Arial font size. Place the date and your name right- justified on the first line. Skip one space and place the title of the paper center-justified. Skip one space and start the body of the report.

5. All Reaction Papers will follow the content template provided below.

DATE_L
NAME/TITLE of PRESENTER/S and/or TITLES of REFERENCES and SOURCES
KEY POINTS and SHORT SUMMARY of the PRESENTATION/S and/or
REFERENCED INFORMAITON
VALUE of the INFORMATION PRESENTED to YOU as a STUDENT
VALUE of the INFORMATION PRESENTED to YOU in YOUR FUTURE
PROFESSIONAL CAREER
YOUR OVERALL REACTION to the INFORMATION and/or PRESENTATION/S
TOPIC/S, SOURCES, and/or PRESENTER/S




\section{Appendix C}

RUBRICS FOR SCORING FINAL DESIGN REPORTS

Department of Civil Engineering North Dakota State University

CE 489 - SENIOR DESIGN

Capstone Experience
Fall Semester Aug. 22 - Dec. 16, 2011

\begin{tabular}{|l|c|c|c|}
\hline \multicolumn{3}{|c|}{ Scoring Checklist for Written Project Reports } \\
\hline \multicolumn{2}{|c|}{ CRITEject Phase: Final Design Report (30\% of course grade) } \\
\cline { 1 - 3 } Group No.: \\
\cline { 1 - 3 } Date: December 9, 2011
\end{tabular}

NOTE: The number(s) after each criterion is (are) course objective number(s) listed in the course syllabus that, in turn, relate to ABET accreditation criteria.

[ Form Date: $8 / 23 / 2011$ ] 


\section{APEENDIX D:}

\section{CAPSTONE GRADES AND PEER ASSESSMENT GRADING}

Team scores in the CE-489 Senior Design (capstone) course are compiled from the Written Reports (Work Plan/Conceptual Design, Mid-semester Preliminary Design, and Final Design), the Project Design Journal, and the Oral Presentations (Preliminary Design and Final Design). The method of assigning individual scores will be determined by each team using the PEER ASSESSMENT AGREEMENT (refer to APPENDIX F). Basically each team decides if they want to take the team score or perform peer evaluation. For the team score each team member would receive an individual score that is equal to the composite team score. Peer evaluation uses a weighted score assigned by each team member.

\section{Example:}

The table below shows the team score components for Team X. The total is calculated by summing each component: Work Plan/Conceptual Design Report (WP/CDR), Mid-semester Preliminary Design Report (MS/PDR), the Mid- semester Oral Presentation (MOP), Final Design Reports (FDR), the Final Oral Presentation (FOP), and the Project Design Journal (PDJ). The table below shows the percentages assigned to each component (from the syllabus) and the actual score assigned to the team for each component.

\begin{tabular}{|c|c|c|c|c|c|c|c|}
\hline \multicolumn{10}{|c|}{ CAPSTONE - TEAM SCORES } \\
\hline & $\begin{array}{c}\text { WP/CDR } \\
10 \mathrm{pts}\end{array}$ & $\begin{array}{c}\text { MS/PDR } \\
20 \mathrm{pts}\end{array}$ & $\begin{array}{c}\text { MOP } \\
10 \mathrm{pts}\end{array}$ & $\begin{array}{c}\text { FDR } \\
30 \mathrm{pts}\end{array}$ & $\begin{array}{c}\text { FOP } \\
10 \mathrm{pts}\end{array}$ & $\begin{array}{c}\text { PDJ } \\
5 \mathrm{pts}\end{array}$ & $\begin{array}{c}\text { TOTAL } \\
85 \mathrm{pts}\end{array}$ \\
\hline Team X & 8.0 & 16.5 & 8.5 & 24.0 & 8.5 & 4.5 & 70 \\
\hline
\end{tabular}

To calculate individual grades - if the group takes the team score:

Let us say Team $X$ agreed to take the team score. This means each member of the team gets 70 pts or $82.3 \%$ of the 85 pts. For the individual receiving 3.0 pts each for the Reaction Papers, the total would be. $70+15.0=85$ points out of 100 total points or $85 \%$ which translates to a letter grade of "B".

\section{To calculate individual grades - if the group uses peer assessment:}

Let us say Team $\mathrm{X}$ agrees to do peer evaluation. The table below shows the peer evaluation for Team $\mathrm{X}$ based on evaluations given to each member by his or her peers. To understand the ratings: John gave Pat, Ellie, and Ralf all a rating of Very Good. John gave Frodo an Unsatisfactory rating. Pat gave Ellie and Ralf a Very Good, gave John an Excellent, and gave Frodo a Satisfactory. Ellie did not want to cause any waves so she gave everyone a Very Good. Ralf gave John an Excellent and Pat and Ellie a Good. Ralf gave Frodo a Marginal. Frodo gave John and Pat an Excellent, Ellie a Very Good and Ralf a Good. The Team Score is still 70 pts. 
The individual averages (Ind. Avg.) are then calculated and a team average (89.4) is computed. The individual averages are divided by the team average to calculate the adjustment factors (Adj. Factor) for each individual member. These adjustment factors are then multiplied by the Team Score (70 pts) to determine the individual scores which are converted to a letter grade. Refer to the table below.

\begin{tabular}{|c|l|l|l|l|l|c|c|c|c|l|}
\hline Team X & John & Pat & Ellie & Ralf & Frodo & Ind. Avg. & $\begin{array}{c}\text { Adj. } \\
\text { Factor }\end{array}$ & $\begin{array}{c}\text { Original Team } \\
\text { Avg. Pts }\end{array}$ & $\begin{array}{c}\text { Adjust'd } \\
\text { Ind Avg Points }\end{array}$ & $\begin{array}{c}\text { Final } \\
\text { Grade }\end{array}$ \\
\hline John & & 100 & 93 & 100 & 100 & 98.25 & 1.1 & 70 & $77+15$ & A \\
\hline Pat & 93 & & 93 & 86 & 100 & 93 & 1.04 & 70 & $72.8+15$ & B \\
\hline Ellie & 93 & 86 & & 86 & 93 & 89.5 & 1 & 70 & $70+15$ & B \\
\hline Ralf & 93 & 86 & 93 & & 86 & 89.5 & 1 & 70 & $70+15$ & B \\
\hline Frodo & 64 & 79 & 93 & 71 & & 76.75 & 0.86 & 70 & $60.2+15$ & C \\
\hline \multicolumn{6}{|l}{ Adjusted Team Average } & $\mathbf{8 9 . 4}$ & & & & \\
\hline
\end{tabular}

Excellent - Always went above and beyond and in a professional manner (tutored teammates, carried more than his/her fair share of the load, someone you would always want on your team)

Very Good - Consistently did what he or she was supposed to do, very well prepared and cooperative

Good - Usually did what he or she was supposed to do, usually prepared to discuss the assignment Satisfactory - Often did what he or she was supposed to do, but minimally prepared to discuss the assignment

Marginal - Sometimes failed to show up or complete the assigned tasks, not very well prepared.

Unsatisfactory - Often failed to show up or complete the assigned tasks, not prepared Deficient - Would show up (sometimes), but totally unprepared

No Show - No participation at all (should not pass the course)

\section{Peer Rating Scale}

Excellent-100; Very Good-93; Good-86; Satisfactory-79; Marginal-71; Unsatisfactory-64; Deficient-57; No Show-50.

\section{APEENDIX E:}

\section{PEER ASSESSMENT AGREEMENT}

The final team scores for the Capstone Course are determined from: 1.) the three written project design reports, 2.) the oral presentations, and 3.) the project journal. For the Capstone course, Peer Assessment will be used to determine individual scores based on the final team score plus the individual's scores on the five reaction paper reports.

We the majority members of Team

agree (select one of the following):

$$
\overline{(\text { No.) }} \quad \text { (Team Name) }
$$

To use the Peer Assessment Method of peer evaluation to determine our individual scores within the team, based on the final team score. 
That the final individual scores will be the final team score plus scores for individual assignments. (This is the default grading method.)

\begin{tabular}{c}
\hline (Name) \\
\hline (Name) \\
\hline (Name) \\
\hline (Name) \\
\hline (Name) \\
\hline (Name)
\end{tabular}

\begin{tabular}{c}
\hline (Date) \\
\hline (Date) \\
\hline (Date) \\
\hline (Date) \\
\hline (Date)
\end{tabular}

\section{APEENDIX F:}

\section{PEER EVALUATION OF TEAM MEMBERS}

Your Name: Team No. Team Name:

Please write the name of all of your other team members (do not include yourself) and rate the degree to which each member fulfilled his/her responsibilities in completing the assigned tasks. The possible ratings are as follows:

Excellent: Always went above and beyond and in a professional manner (tutored teammates, carried more than his/her fair share of the load, someone you would always want on your team)

Very Good: Consistently did what he or she was supposed to do, very well prepared and cooperative

Good: Usually did what he or she was supposed to do, usually prepared to discuss the assignment

Satisfactory: Often did what he or she was supposed to do, but minimally prepared to discuss the assignment

Marginal: Sometimes failed to show up or complete the assigned tasks, not very well prepared

Unsatisfactory: Often failed to show up or complete the assigned tasks, not prepared

Deficient: Would show up (sometimes), but totally unprepared

No Show: No participation at all (should not pass the course)

These ratings should reflect each individual's level of participation, effort, and sense of responsibility, and not his or her academic ability.

Name of Team Member

\section{Rating}

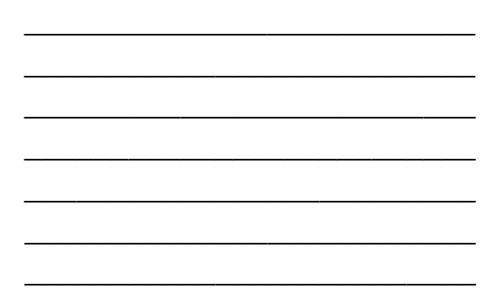

Your Signature 
APEENDIX G:

\section{CAPSTONE DESIGN PROJECT JOURNAL}

1. Each capstone project design team will keep a journal of their project design activities.

2. Journal entries will be made weekly and be available for review during the team meeting with an assigned faculty mentor.

3. Journal entries will be uploaded to the NDSU course Blackboard (Bb) site and the original will be kept on file by the team.

4. All weekly journal entries will use the journal entry template provided below.

5. The final project journal will be the collection of the weekly journal entries.

6. The final project journal will be submitted to the faculty mentors and the course coordinator on the same date as the final design report. The final project journal can be placed inside the final report binder.

7. The final project journal will be assessed at $5 \%$ of the total course grade. (sum of weekly journal scores/\# of weekly journals scored).

8. Capstone mentors will evaluate the following criteria; Work Plan Status, Design Task Details, Format Layout, Completeness, Neatness, Grammar, and Spelling to score the final project journal.

JOURNAL ENTRY TEMPLATE

\begin{tabular}{|ll}
\hline TEAM \#_ TEAM NAME_ & \\
JOURNAL ENTRY SUBMITTAL DATE & \\
WORK PLAN STATUS & \\
DESIGN TASK DETAILS & \\
ENVIRONMENTAL TASK & TEAM MEMBER NAME \\
PROJECT ACTIVITY DETAILS & \\
GEOTECHNICAL TASK & TEAM MEMBER NAME \\
PROJECT ACTIVITY DETAILS & TEAM MEMBER NAME \\
STRUCTURAL TASK & \\
PROJECT ACTIVITY DETAILS & TEAM MEMBER NAME \\
TRANSPORTATION TASK & \\
PROJECT ACTIVITY DETAILS & TEAM MEMBER NAME \\
WATER RESOURCES TASK & DATE: \\
PROJECT ACTIVITY DETAILS & SCORE (0-5 points): \\
TEAM MENTOR SIGNATURE: & \\
& \\
&
\end{tabular}




\title{
ORGANIZING and WRITING the REPORTS
}

\author{
[Conceptual Design, Preliminary Design, and Final Design Reports]
}

\section{The Written Project Report Must Include:}

- A Letter of Transmittal is the first page and is in front of the title page.

- A specific project-related "Title" page that includes the project name, your team's company name if one is used, team number, team member names, date, etc.) This information should also be provided on the front of the project 3-ring binder.

- A "Table of Contents" (TOC), either for the entire project report or prior to each of the task sections.

- "List of Tables" and a "List of Figures" as separate page/s or included at the end of the TOC

- A project design "Executive Summary" after the Table of Contents and List of Table and Figures. The Executive Summary briefly summarizes the project design work completed to date.

- The report begins with the "Project Statement" followed by an "Introduction" or "Background" summary.

- The Project Text / Narrative is divided into chapters and/or sections and subheadings for each task.

- Summary tables are included in the narrative. Make sure to reference the information in the tables that are included in the body of the report. It must have been compiled from another source which may be included in your appendices, either way - a reference is required.

- Make sure to reference all figures that are included in the body of the report.

- A reference section is included at the end of the project narrative and before the appendices. All items that are included as references must be "referenced" in the report through the use of proper referencing methods or footnotes. Source references include; texts, tutorials, papers, project documents, manuals, software, etc.

\section{Report Format:}

- Each main task area will comprise a separate chapter or section of the report.

- Each chapter or section will be immediately followed by the appendices relative to that task.

- Chapter titles and section or sub-section headings within the text / narrative are required.

- Typed page numbers are required except that appendices pages can be numbered by hand.

- Make sure to reference all figures in the report that are from other sources.

- Tables and figures (charts, graphs, drawings, etc.) must have titles. Table titles are located at the top of the table. Figure titles are located beneath the figure. Numbers are included with tables and figures (e.g., Table 1- Cost Estimate Summary, Figure 4.2 - Plan View). Tables and figures must be numbered sequentially. 


\section{Appendices to be included with the written report:}

- Include all supplemental material, such as; design calculations, material estimates, cost estimates, additional tables and figures, etc. in the appendices. An appendix must be included following each chapter or section task of the report text / narrative.

- All material contained in the appendices must be referenced in the project report text / narrative. You can't just throw stuff in an appendix and expect the reader to find it.

- A title page must be included with each appendix of the appendices. The title page includes the appendix letter (or number), an appropriate title, and a list of contents. For example; Appendix A - Hydrological Analysis [Source or Reference: textbook title, author, publisher, edition 2003 (pages 223-261)] or Appendix C - Cost Estimate [Source or Reference: R. S. Means Cost Data - 1997 (pages 157-164)]. 